\title{
Pathological complete response and
} prognosis after neoadjuvant chemotherapy for HER2-positive breast cancers before and after trastuzumab era: results from a real-life cohort

Anne-Sophie Hamy, Lisa Belin, Hélène Bonsang-Kitzis, Caroline Paquet, Jean-Yves Pierga, Florence Lerebours, Paul Cottu, Roman Rouzier, Alexia Savignoni, Marick Lae and Fabien Reyal

Correction to: British Journal of Cancer (2016) 114, 45-52. doi:10.1038/bjc.2015.426; published online 10 December 2015

The first author of this article is incorrectly listed as AnneSophie Hamy-Petit in the original article and should be AnneSophie Hamy.
This work is published under the standard license to publish agreement. After 12 months the work will become freely available and the license terms will switch to a Creative Commons Attribution-NonCommercialShare Alike 4.0 Unported License. 